Jurnal Keperawatan Silampari

Volume 2, Nomor 2, Juni 2019

e-ISSN: 2581-1975

p-ISSN: 2597-7482

DOI: https://doi.org/10.31539/jks.v2i2.530

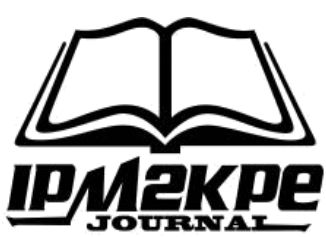

\title{
PENGARUH EDUKASI MEDIA VIDEO DAN FLIPCHART TERHADAP MOTIVASI DAN SIKAP ORANGTUA DALAM MERAWAT BALITA DENGAN PNEUMONIA
}

\author{
Harsismanto $\mathbf{J}^{1}$, Suhendar Sulaeman ${ }^{2}$ \\ Program Studi Ilmu Keperawatan Universitas Muhammadiyah Bengkulu ${ }^{1}$, \\ Program Studi Magister Keperawatan, Universitas Muhammadiyah Jakarta ${ }^{2}$ \\ harsismanto@gmail.com ${ }^{1}$
}

\begin{abstract}
ABSTRAK
Penelitian ini bertujuan untuk mengetahui pengaruh pemberian edukasi dengan media video dan flip chart terhadap motivasi dan sikap orangtua dalam merawat balita dengan pneumonia. Jenis penelitian ini adalah quasi eksperimen dengan rancangan non randomized without control group pretest-posttestdesign. Hasil penelitian didapatkan ada perbedaan rata-rata skor motivasi dan sikap orangtua dalam merawat balita dengan pneumonia sebelum dan sesudah pemberian edukasi. Pada kelompok media video $\rho$ value motivasi $(0,001)$ dan sikap $(0,000)$, pada kelompokmedia flip chartdengan $\rho$ value motivasi $(0,002)$ dan sikap $(0,000)$ dan pada kelompokkombinasi media video dan flip chartdengan $\rho$ value motivasi $(0,000)$ serta sikap $(0,000)$. Simpulan, ada pengaruh yang signifikan penggunaan media edukasi dalam pemberian edukasi terhadap peningkatan rata-rata skor motivasi dan sikap orangtua dalam merawat balita dengan pneumonia. Kombinasi edukasi dengan menggunakan media video dan flip chart memberikan hasil yang lebih efektif daripada kelompok edukasi yang lain.
\end{abstract}

Kata Kunci: Media Pendukung, Motivasi, Pendidikan Kesehatan, Sikap

\begin{abstract}
This study aims to determine the effect of providing education with video media and flip charts on the motivation and attitudes of parents in caring for toddlers with pneumonia. This type of research is a quasi-experimental design with a non randomized without control group pretest-posttestdesign. The results showed there were differences in the average score of motivation and attitudes of parents in caring for toddlers with pneumonia before and after providing education. In the video media group $\rho$ motivation value (0.001) and attitude (0,000), in the media group flip chart with $\rho$ motivation value (0.002) and attitude $(0,000)$ and in the video media and flip chart combination group with $\rho$ motivation value $(0,000)$ and attitude $(0,000)$. Conclusion, there is a significant influence of the use of educational media in providing education to an increase in the average score of motivation and attitudes of parents in caring for children with pneumonia. The combination of education using video media and flip charts gives more effective results than other education groups.
\end{abstract}

Keywords: Supporting Media, Motivation, Health Education, Attitudes 


\section{PENDAHULUAN}

Salah satu penyebab kematian tertinggi akibat penyakit infeksi pada anak usia balita adalah penyakit pneumonia (WHO-UNICEF, 2009). Said (2010) menyatakan penyebab utama pneumonia balita adalah kuman streptococcus, pneumococcus dan hemophilus influenzae type B/Hib, diikuti Staphylococcus aureus dan Klebsiela pneumoniae pada kasus berat, adapun gejala penyakit pneumonia yaitu menggigil, demam, sakit kepala, batuk, mengeluarkan dahak, dan sesak napas.

Pneumonia menyumbang $16 \%$ dari 5,9 juta kematian balita di dunia dan menjadi penyebab 920.136 anak-anak meninggal dunia di tahun 2015 (WHO, 2016) sedangkan di Indonesia pada tahun 2015 angka kejadian pneumonia pada balita yang ditemukan dan ditangani sebanyak 554.650 kasus dari target penemuan kasus sebanyak 874.195 $(63,45 \%)$. Angka kematian akibat pneumonia pada balita tahun 2015 sebesar $0,16 \%$ lebih tinggi dibandingkan dengan tahun 2014 sebesar 0,08\% (Kemenkes RI, 2015\& 2016). Berdasarkan kelompok umur, period prevalence pneumonia yang tertinggi pada kelompok umur 1-4 tahun, period prevalence pneumonia balita di Indonesia adalah 18,5 per mil (Kemenkes RI, 2013).

Provinsi Bengkulu meskipun tidak termasuk dalam 10 besar angka kejadian pneumonia di Indonesia, namun angka kejadiannya mengalami perubahan yang fluktuatif setiap tahun. Data Riskesdas (2013) period prevalence dan prevalensi pneumonia di Provinsi Bengkulu yaitu 0,8\% dan 2,7\%. Berdasarkan data dinas kesehatan provinsi pada tahun 2013, dari 18.170 kasus perkiraan penderita pneumonia, sebanyak 1.225 penderita ditemukan dan ditangani (6,7\%). Pada tahun 2014 terjadi peningkatan jumlah kasus, dari 19.164 kasus perkiraan, tetapi yang ditemukan dan ditangani sebanyak 48.601 penderita (254\%). Pada tahun 2015, sebanyak 15.694 kasus perkiraan pneumonia, sebanyak $1.818(12 \%)$ penderita ditemukan dan ditangani (Dinkes Provinsi Bengkulu, 2014; 2015 \& 2016).

Pneumonia pada balita perlu mendapat perhatian, tingginya angka kejadian pneumonia pada balita apabila tidak ditangani dengan benar maka dikhawatirkan dapat menghambat upaya mencapai target MDGs yang sejak tahun 2016 dilanjutkan dengan SDGs (Sustainable Development Goals) tahun 2015-2030, Salah satu tujuan dari program SDGs yaitu memastikan hidup yang sehat dan menggalakkan kesejahteraan untuk semua usia, target spesifik dari tujuan ini adalah menurunkan angka kematian pada bayi dan anak. Penurunan angka kematian bayi dan anak menjadi 25 per 1000 kelahiran hidup pada 2030 (WHO, 2015).

Pelaksanaan pencegahan dan pengendalian kejadian pneumonia pada anak balita sejauh ini belum merata dan masih tidak terkoordinasi (WHO-UNICEF, 2009). Hanya $54 \%$ anak dengan pneumonia di negara berkembang dilaporkan dan dibawa ke penyedia layanan kesehatan yang berkualitas dan hanya 19\% anak balita dengan tanda-tanda klinis pneumonia mendapatkan antibiotik. Selain itu, walaupun telah tersedia sebuah metode pendekatan terpadu untuk pelayanan kesehatan anak (MTBS) dan upaya peningkatan kualitas pelayanan, pelaksanaanya masih jauh dari yang diharapkan, sehingga mengakibatkan angka kejadian pneumonia masih tinggi (Webber, Fransisca, 2010).

Perawat punya peranan penting dalam memberikan pemahaman tentang penyakit pada anak dan orangtua Proses pemberian informasi ini dapat dilakukan dengan melakukan pendidikan kesehatan yang menjadi bagian penting dalam intervensi keperawatan (Perry, Potter, 2010). Tujuan pendidikankesehatan adalah terjadinya perubahan sikap dan tingkah laku sehingga mampu berperan aktif dalam upaya 
mewujudkan derajat kesehatan yang optimal Nursalam, Effendi (2008) tujuan ini sejalan dengan teori model keperawatan health promotion model (HPM) yang dikembangkan oleh Nola J. Pender, yang mengemukakan promosi kesehatan berupa edukasi kesehatan pada klien dan keluarga merupakan tindakan positif yang mengarahkan pada perubahan perilaku (Alligood, 2014). Sehingga dengan pendidikan kesehatan yang diberikan dapat meningkatkan pengetahuan dan pemahaman orangtua dalam pencegahan dan perawatan balita pneumonia, yang akhirnya diharapkan dapat menurunkan angka kejadian pneumonia pada balita.

Pemberian edukasi kepada orangtua memerlukan media pendukung.Media yang menarik akan memberikan keyakinan, sehingga perubahan kognitif, afektif dan psikomotor dapat dipercepat (Setiawati, Dermawan, 2008). Media yang dapat digunakan sebagai alat bantu untuk memberikan edukasi pada klien dan keluarga adalah media audiovisual (video) dan flip chart.

Media audiovisual disebut juga dengan media video saat ini mulai banyak digunakan karena media ini merupakan alat peraga yang dapat didengar dan dilihat sehingga membantu peserta didik dalam proses pembelajaran yang berfungsi memperjelas atau mempermudah dalam memahami pengetahuan yang sedang dipelajari (Arsyad, 2014). Notoatmodjo (2010) menjelaskan flip chart adalah media kesehatan yang berbentuk lembar balik, dimana tiap lembarnya berisi gambar peraga dan dibaliknya ada informasi yang berkaitan dengan gambar tersebut, lebih lanjut Maulana (2009) menjelaskan ada beberapa kelebihan menggunakan media flip chart sehingga banyak ditemukan di intansi kesehatan, yaitu; flip chart merupakan media yang cocok untuk kebutuhan dalam ruangan atau luar ruangan, dapat dibuat dari alat dan bahan sederhana; mudah dibawa kemana-mana; flip chart mengandung tulisan dan gambar yang menarik perhatian pembaca ketika membaca informasi yang terdapat didalam flip chart.

Beberapa penelitian yang meneliti pengaruh penggunaan media audio visual (video) dan flip chart terhadap perubahan motivasi dan sikap telah dilakukan, seperti penelitian yang dilakukan oleh Kapti, Rustiana \& Widyatuti (2013) yang meneliti efektifitas audiovisual sebagai media penyuluhan kesehatan terhadap peningkatan pengetahuan dan sikap ibu dalam tatalaksana balita dengan diare. Hasilnya terjadi peningkatan pengetahuan dan sikap setelah penyuluhan.

Penelitian yang menggunakan flip chart sebagai media edukasi dalam meningkatkan pengetahuan dan sikap juga dilakukan oleh Yunita, Raharjo (2013) yang meneliti tentang pengaruh penyuluhan dengan media flip chart terhadap pengetahuan dan sikap masyarakat dalam program eleminasi filariasis mendapatkan hasil ada pengaruh penyuluhan dengan menggunakan media flip chart terhadap pengetahuan dan sikap masyarakat,95,55\% masyarakat berpengetahuan baik setelah penyuluhan dan $74,20 \%$ masyarakat memiliki sikap sangat baik setelag penyuluhan.

Tujuan penelitian ini untuk mengetahui pengaruh pemberian edukasi dengan menggunakan media video dan flip chart terhadap motivasi dan sikap orangtua dalam merawat balita dengan pneumonia, sehingga dapat menjadi bahan masukan dan pertimbangan bagi pelayanan keperawatan dan tenaga kesehatan lain di rumah sakit dalam meningkatkan motivasi serta sikap orangtua dalam merawat balita dengan pneumonia dengan menggunakan media video tidak hanya media cetak saja. 


\section{METODE PENELITIAN}

Penelitian ini merupakan penelitian kuantitatif dengan desain penelitian "Quasi Experimental", rancangan penelitian yaitu non randomized without control group pretest-posttest. Populasi yang diambil dari penelitian ini adalah orangtua yang memiliki balita dengan pneumonia dan dirawat di Rumah Sakit.

Sampel dalam penelitian ini sebanyak 30 sampel, dengan teknik pengambilan sampel non probability sampling jenis consecutive sampling yang dibagi dalam tiga kelompok intervensi, yaitu kelompok edukasi menggunakan media video, kelompok edukasi menggunakan flip chart dan kelompok edukasi menggunakan kombinasi media video dan flip chart dengan jumlah sampel masing-masing kelompok intervensi sebanyak 10 responden. Sampel diambil berdasarkan kriteria inklusi yaitu; 1) orangtua sebagai responden dalam penelitian iniadalah ibu yang mempunyai balita didiagnosa pneumonia dan dirawat, 2) orangtua bersedia berpartisipasi sebagai responden dalam penelitian, 3) orangtua mampu membaca, menulis dan berkomunikasi, 4) orangtua balita tidak mengalami gangguan penglihatan dan pendengaran serta orangtua balita yang mengikuti proses penelitian sampai selesai.

Penelitian dilaksanakan di ruang perawatan anak RSUD Kota Bengkulu, dari bulan April 2017 sampai dengan Juni 2017.Proses penelitian di awali dengan kegiatan pre-test yang dilakukan sebelum pemberian edukasi. Responden kelompok edukasi menggunakan media video akan diperlihatkan materi melalui video yang dilakukan selama lebih kurang 20 menit sebanyak 2 kali pertemuan. Pada kelompok edukasi mengunakan media flip chart pemberian edukasi juga dilakukan selama lebih kurang 20 menit sebanyak 2 kali pertemuan, sedangkan pada kelompok edukasi kombinasi media video dan flip chart edukasi diberikandengan waktu lebih lama kurang lebih 30 menit atau menyesuaikan dengan kondisi responden karena menggunakan dua media sekaligus dan diberikan sebanyak 2 kali pertemuan. Setelah penyuluhan kesehatan selesai sebanyak 2 kali pertemuan maka langsung dilakukan post test untuk mengukur motivasi dan sikap orangtua. Data hasil penelitian ini diolah dengan program statistik dengan menggunakan uji t dependen (uji dependen $t$ - test).

\section{HASILPENELITIAN}

Analisis Univariat

Karakteristik responden berdasarkan umur

Tabel. 1

Distribusi Frekuensi Karakteristik Responden Berdasarkan Umur Orangtua (N=30)

\begin{tabular}{lccccc}
\hline \multicolumn{1}{c}{ Variabel } & Mean & Median & SD & $\begin{array}{c}\text { Minimal- } \\
\text { Maksimal }\end{array}$ & 95\% CI \\
\hline Edukasi dengan video & 29,90 & 30,50 & 4,581 & $22-37$ & $26,62-33,18$ \\
\hline Edukasi dengan flip chart & 27,80 & 29,00 & 6,408 & $17-37$ & $23,75-36,05$ \\
\hline Edukasi dengan video danflip chart & 29,10 & 29,00 & 3,107 & $22-33$ & $26,88-31,32$ \\
\hline
\end{tabular}

Hasil analisis distribusi frekuensi karakteristik responden berdasarkan umur orangtua pada tabel 1.menunjukkan rata-rata umur orangtua pada kelompok edukasi dengan media video 29,90 tahun, umur termuda adalah 22 tahun dan umur tertua 37 tahun. Adapun rata-rata umur orangtua pada kelompok edukasi dengan media flip chart 27,80 tahun, umur termuda 17 tahun dan umur tertua 37 tahun. Sedangkan pada kelompok edukasi dengan media video dan flip chart rata-rata umur orangtua adalah 29,10 tahun, dengan umur termuda 22 tahun dan umur tertua 33 tahun. 


\section{Karakteristik Responden Berdasarkan Pendidikan, Status Bekerja dan Informasi Mengenai Pneumonia Sebelumnya}

Tabel. 2

Distribusi Karakteristik Responden Berdasarkan Pendidikan, Status Bekerja dan Informasi Mengenai Pneumonia Sebelumnya $(n=30)$

\begin{tabular}{|c|c|c|c|c|c|c|c|c|}
\hline \multirow[t]{2}{*}{ Variabel } & \multicolumn{2}{|c|}{$\begin{array}{c}\text { Edukasi } \\
\text { dengan video } \\
\mathrm{n}=10\end{array}$} & \multicolumn{2}{|c|}{$\begin{array}{c}\text { Edukasi } \\
\text { dengan flip } \\
\text { chart } \\
\mathrm{n}=10\end{array}$} & \multicolumn{2}{|c|}{$\begin{array}{c}\text { Edukasi } \\
\text { dengan video } \\
\text { dan flip chart } \\
\mathrm{n}=10\end{array}$} & \multicolumn{2}{|c|}{$\begin{array}{l}\text { Total } \\
\mathrm{N}=30\end{array}$} \\
\hline & $\mathrm{F}$ & $\%$ & $\mathrm{~F}$ & $\%$ & $\mathrm{f}$ & $\%$ & $\mathrm{f}$ & $\%$ \\
\hline \multicolumn{9}{|l|}{ Pendidikan } \\
\hline 1. Pendidikan tinggi & 8 & 80 & 7 & 70 & 10 & 100 & 25 & 83,3 \\
\hline 2. Pendidikan rendah & 2 & 20 & 3 & 30 & 0 & 0 & 5 & 16,7 \\
\hline \multicolumn{9}{|l|}{ Status Bekerja } \\
\hline 1. Bekerja & 4 & 40 & 2 & 20 & 7 & 70 & 13 & 43,3 \\
\hline 2. Tidak bekerja & 6 & 60 & 8 & 80 & 3 & 30 & 17 & 56,7 \\
\hline \multicolumn{9}{|l|}{ Informasi mengenai pneumonia } \\
\hline 1. Pernah mendapat informasi & 2 & 20 & 1 & 10 & 2 & 20 & 5 & 16,7 \\
\hline $\begin{array}{l}\text { 2. Belum pernah mendapat } \\
\text { informasi }\end{array}$ & 8 & 80 & 9 & 90 & 8 & 80 & 25 & 83,3 \\
\hline
\end{tabular}

Karakteristik responden berdasarkan pendidikan pada tabel 2 didapatkan sebagian besar responden berpendidikan tinggi $(83,3 \%)$, pada kelompok edukasi dengan media video didapatkan responden dengan pendidikan tinggi sebanyak 8 responden $(80 \%)$, demikian pula pada kelompok edukasi dengan media flip chart responden dengan pendidikan tinggi sebanyak 7 responden (70\%) sedangkan pada kelompok edukasi dengan media video dan flip chart mayoritas responden (100\%) berpendidikan tinggi.

Karakteristik responden berdasarkan status bekerja, pada kelompok edukasi dengan media video didapatkan responden bekerja yaitu sebanyak4 responden (40\%), pada kelompok edukasi dengan media flip chart sebagian besar responden tidak bekerja yaitu sebanyak 8 responden (80\%), adapun pada kelompok edukasi dengan media video dan flip chart sebanyak 7 responden $(70 \%)$ bekerja.

Berdasarkan hasil analisis tabel 2 menunjukkan karakteristik responden berdasarkan informasi mengenai pneumonia yang diterima sebelumnya. Pada kelompok edukasi dengan menggunakan media video didapatkan sebagian besar responden belum pernah menerima informasi mengenai pneumonia (80\%), pada kelompok edukasi dengan media flip chartdidapatkan mayoritas responden (90\%) belum pernah menerima informasi tentang pneumonia, demikian pula pada kelompok edukasi menggunakan media video dan flip chart 8 responden $(80 \%)$ belum pernah menerima informasi tentang pneumonia. 


\section{Distribusi Frekuensi Motivasi dan Sikap Orangtua}

Tabel. 3

Distribusi Motivasi dan Sikap Orangtua dalam Merawat Balita dengan Pneumonia Sebelum dan Sesudah Pemberian Edukasi pada Masing-Masing Kelompok Intervensi $(\mathrm{n}=30)$

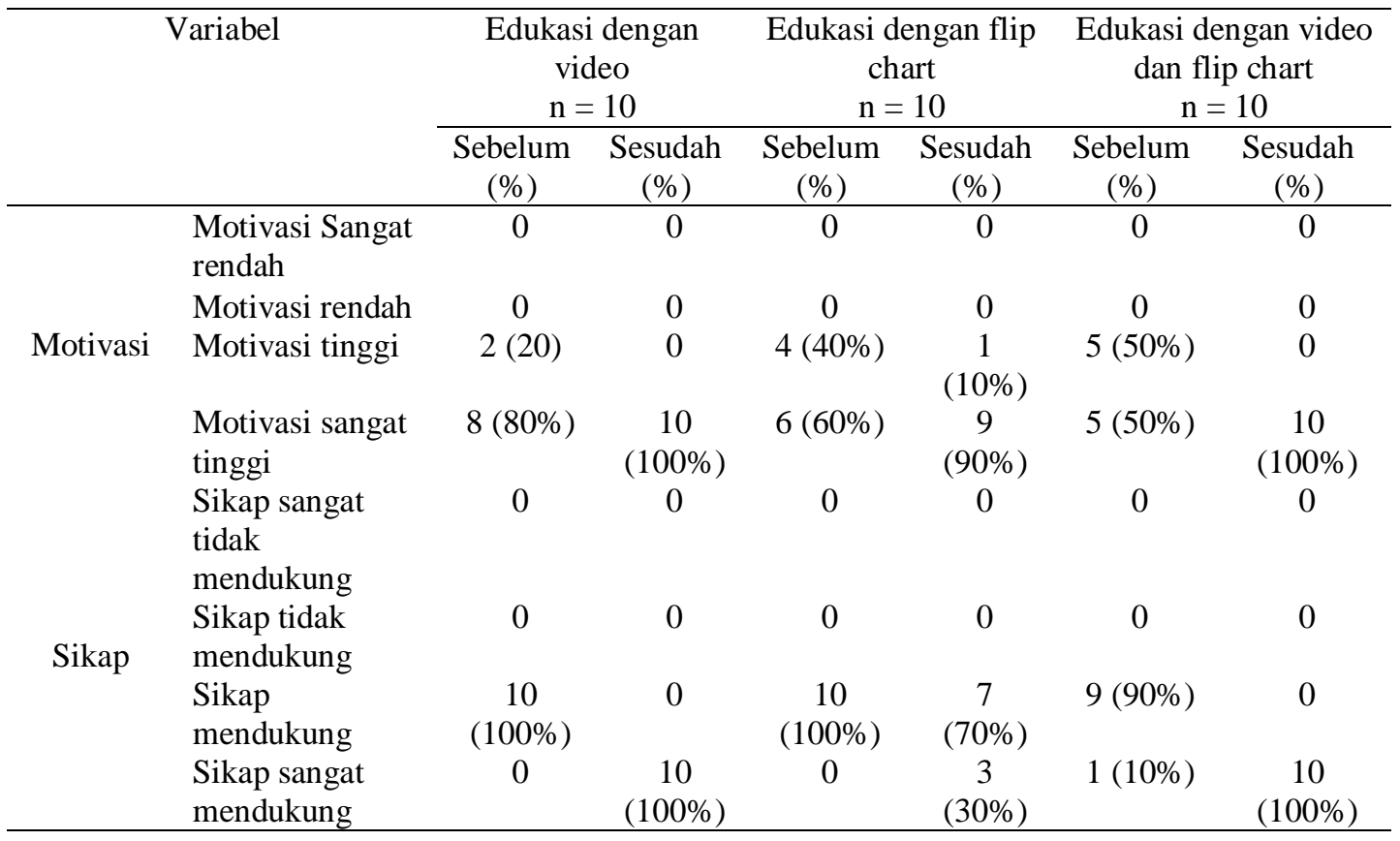

Hasil analisis dari Tabel 3 menunjukkan distribusi motivasi dan sikap orangtua dalam merawat balita dengan pneumonia sebelum dan sesudah diberikan edukasi. Kelompok yang diberikan edukasi menggunakan media video didapatkan peningkatan motivasi responden, dimana sebelum diberikan edukasi mayoritas memiliki motivasi sangat tinggi, yaitu $80 \%$ (8 responden), sesudah pemberian edukasi seluruh responden (100\%) memiliki motivasi sangat tinggi dalam merawat balita dengan pneumonia, adapun sikap responden pada kelompok edukasi dengan menggunakan media video sebelum diberikan edukasi didapatkan seluruh (100\%) responden memiliki sikap mendukung, setelah diberikan edukasi seluruh responden (100\%) memiliki sikap sangat mendukung dalam merawat balita dengan pneumonia.

Kelompok edukasi dengan menggunakan media flip chart didapatkan 6 responden (60\%) memiliki motivasi tinggi sebelum diberikan edukasi, setelah pemberian edukasi motivasi responden mengalami peningkatan, dimana mayoritas responden $(90 \%)$ memiliki motivasi sangat tinggi, dan masih ada 1 (10\%) responden dengan motivasi tinggi. Adapun distribusi sikap responden sebelum pemberian edukasi didapatkan seluruh responden (100\%) memiliki sikap mendukung, setelah diberikan edukasi terjadi peningkatan sikap, didapatkan sebanyak 7 responden (70\%) memiliki sikap mendukung dan 3 responden (30\%) memiliki sikap sangat mendukung.

Kelompok edukasi dengan menggunakan media kombinasi video dan flip chart, berdasarkan tabel 5.3 didapatkan hasil 5 (50\%) responden memiliki motivasi tinggi sebelum diberikan edukasi, sesudah pemberian edukasi motivasi responden mengalami peningkatan dimana seluruh responden (100\%) memiliki motivasi sangat tinggi dalam merawat balita dengan pneumonia. Adapun distribusi sikap responden pada kelompok edukasi menggunakan media video dan flip chart sebelum diberikan edukasididapatkan 
sebagian besar responden (90\%) memiliki sikap mendukung, setelah pemberian edukasi didapatkan seluruh responden $(100 \%)$ memiliki sikap sangat mendukung dalam merawat balita dengan pneumonia.

\section{Analisis Bivariat}

\section{Perbedaan Rata-Rata Skor Motivasi dan Sikap Orangtua dalam Merawat Balita dengan Pneumonia Sebelum dan Sesudah Pemberian Edukasi pada Masing- Masing Kelompok Intervensi}

Analisis yang digunakan untuk mengetahui adanya perbedaan rata-rata skor motivasi dan sikap orangtua sebelum dan sesudah pemberian edukasi pada ketiga kelompok intervensi adalah paired t-test. perbedaan peningkatan motivasi dan sikap orangtua diidentifikasi dari selisih skor motivasi dan sikap antara pretest dengan posttest pada masing-masing kelompok. Hasil analisis ditunjukkan pada tabel dibawah ini, yaitu;

Tabel. 4

Perbedaan Rata-Rata Skor Motivasi Orangtua Sebelum dan Sesudah Pemberian Edukasi pada Masing-Masing Kelompok Edukasi (N=30)

\begin{tabular}{|c|c|c|c|c|c|c|c|}
\hline Variabel & Kelompok & $\mathrm{N}$ & Mean & SD & $\begin{array}{l}\text { Beda } \\
\text { Mean }\end{array}$ & $\rho$ value & $95 \% \mathrm{CI}$ \\
\hline \multirow{9}{*}{ Motivasi } & Edukasi dengan & a vic & & & \multirow{3}{*}{4,6} & \multirow{3}{*}{0,001} & \multirow{3}{*}{$2,628-6,572$} \\
\hline & Sebelum & 10 & 71,50 & 6,115 & & & \\
\hline & Sesudah & 10 & 76,10 & 4,332 & & & \\
\hline & \multicolumn{6}{|c|}{ Edukasi dengan media flip chart } & \multirow{3}{*}{$3,100-9,500$} \\
\hline & Sebelum & 10 & 67,00 & 5,944 & \multirow{2}{*}{6,3} & \multirow{2}{*}{0,002} & \\
\hline & Sesudah & 10 & 73,30 & 4,332 & & & \\
\hline & \multicolumn{6}{|c|}{ Edukasi dengan media video dan flip chart } & \multirow{3}{*}{$4,673-8,927$} \\
\hline & Sebelum & 10 & 66,60 & 4,551 & \multirow{2}{*}{6,8} & \multirow{2}{*}{0,000} & \\
\hline & Sesudah & 10 & 73,40 & 3,627 & & & \\
\hline
\end{tabular}

Ket : Hasil Uji paired t-test

Berdasarkan hasil analisis pada tabel 4 diperoleh rata-rata skor motivasi sebelum pemberian edukasi pada kelompok edukasi menggunakan media video yaitu 71,50 dengan standar deviasi 6,111, sedangkan rata-rata skor motivasi sesudah diberikan edukasi yaitu 76,10, dengan standar deviasi 4,332. Perbedaan skor motivasi sebelum dan sesudah diberikan edukasi sebesar 4,6. Hasil Ujistatistik didapatkan $\rho$ value 0,001 $(\rho<0,05)$ yang berarti ada perbedaan yang signifikan rata-rata skor motivasi sebelum dan sesudah diberikan edukasi menggunakan media video dengan keyakinan $95 \%$.

Kelompok edukasi dengan menggunakan media flip chart, berdasarkan hasil uji statistik diperoleh rata-rata skor motivasi sebelum diberikan edukasi yaitu 67,00 dengan standar deviasi 5,944, dan rata-rata skor motivasi setelah diberikan edukasi yaitu 73,30 dengan standar deviasi 4,332, sedangkan perbedaan skor motivasi sebelum dan sesudah diberikan edukasi sebesar 6,3. Hasil uji statistik didapatkan $\rho$ value $0,002(\rho<0,05)$ yang berarti ada perbedaan yang signifikan rata-rata skor motivasi sebelum dan sesudah diberikan edukasi menggunakan media flip chart dengan keyakinan 95\%.

Rata-rata skor motivasi sebelum diberikan edukasi pada kelompok edukasi menggunakan media video dan flip chart yaitu 66,60 dengan standar deviasi 4,511 dan sesudah diberikan edukasi diperoleh rata-rata skor motivasi yaitu 73,40 dengan standar deviasi 3,627 dengan perbedaan skor motivasi sebelum dan sesudah pemberian edukasi sebesar 6,8. Hasil uji statistikdidapatkan nilai $\mathrm{p} 0,000(\mathrm{p}<0,05)$ yang berarti ada 
perbedaan signifikan skor motivasi sebelum dan sesudah diberikan edukasi menggunakan media video dan flip chart dengan keyakinan $95 \%$.

Tabel. 5

Perbedaan Rata-Rata Skor Sikap Orangtua Sebelum dan Sesudah Pemberian Edukasi pada Masing-Masing Kelompok Edukasi $(\mathrm{N}=30)$

\begin{tabular}{|c|c|c|c|c|c|c|c|}
\hline Variabel & Kelompok & $\mathrm{N}$ & Mean & SD & $\begin{array}{l}\text { Beda } \\
\text { Mean }\end{array}$ & Pvalue & $95 \% \mathrm{CI}$ \\
\hline \multirow{9}{*}{ Sikap } & Edukasi deng & hedi & deo & & & & \multirow{3}{*}{$10,759-16,641$} \\
\hline & Sebelum & 10 & 52,90 & 3,985 & \multirow{2}{*}{13,7} & \multirow{2}{*}{0,000} & \\
\hline & Sesudah & 10 & 66,60 & 3,471 & & & \\
\hline & \multicolumn{6}{|c|}{ Edukasi dengan media flip chart } & \multirow{3}{*}{$4,625-7,775$} \\
\hline & Sebelum & 10 & 52,50 & 3,689 & \multirow{2}{*}{6,2} & \multirow{2}{*}{0,000} & \\
\hline & Sesudah & 10 & 58,70 & 3,561 & & & \\
\hline & \multicolumn{6}{|c|}{ Edukasi dengan media video dan flip chart } & \multirow{3}{*}{$10,487-13,913$} \\
\hline & Sebelum & 10 & 51,70 & 3,802 & \multirow{2}{*}{12,2} & \multirow{2}{*}{0,000} & \\
\hline & Sesudah & 10 & 63,90 & 3,381 & & & \\
\hline
\end{tabular}

Ket : Hasil Uji paired t-test

Berdasarkan hasil analisis tabel 5 diperoleh rata-rata skor sikap sebelum diberikan edukasi pada kelompok edukasi menggunakan media video yaitu 52,90 dengan standar deviasi 3,985, sedangkan rata-rata skor sikap setelah pemberian edukasi yaitu 66,60 dengan standar deviasi 3,471. Perbedaan skor sikap sebelum dan sesudah diberikan edukasi sebesar 13,7. Hasil ujistatistik didapatkan $\rho$ value $0,000(\rho<0,05)$ yang berarti ada perbedaan yang signifikan rata-rata skor sikap sebelum dan sesudah pemberian edukasi menggunakan media video dengan keyakinan $95 \%$.

Kelompok edukasi dengan menggunakan media flip chart berdasarkan hasil uji paired t-test dari tabel 5.6 didapatkan rata-rata skor sikap sebelum pemberian edukasi yaitu 52,50 dengan standar deviasi 3,689, sedangkan rata-rata skor sikap setelah pemberian edukasi yaitu 58,70 dengan standar deviasi 3,651. Perbedaan skor sikap sebelum dan sesudah diberikan edukasi sebesar 6,2. Hasil ujistatistik didapatkan $\rho$ value $0,000(\rho<0,05)$ yang berarti ada perbedaan yang signifikan rata-rata skor sikap sebelum dan sesudah pemberian edukasi menggunakan media flip chart dengan keyakinan $95 \%$.

Rata-rata skor sikap pada kelompok edukasi dengan menggunakan media video dan flip chart sebelum pemberian edukasi sebesar 51,70 dengan standar deviasi 3,802 dan sesudah pemberian edukasi rata-rata skor sikap responden yaitu 63,90 dengan standar deviasi 3,381. Perbedaan skor sikap responden sebelum dan sesudah diberikan edukasi yaitu 12,2. Hasil uji statistik didapatkan nilai $\rho$ value $0,000(\mathrm{p}<0,05)$ yang berarti ada perbedaan signifikan rata-rata skor sikap sebelum dan sesudah diberikan edukasi menggunakan media video dan flip chart dengan keyakinan $95 \%$.

\section{PEMBAHASAN}

\section{Karakteristik responden berdasarkan usia, pendidikan, status bekerja dan informasi sebelumnya tentang pneumonia}

Umur orangtua sebagai responden dalam penelitian ini berdasarkan tabel 1 ratarata untuk kelompok edukasi dengan media video adalah 30 tahun, pada kelompok edukasi dengan media flip chart rata-rata usia orangtua 28 tahun dan pada kelompok kombinasi pemberian edukasi dengan menggunakan media video dan flip chart rata-rata usia orangtua 29 tahun. Mayoritas usia responden menunjukkan waktu reproduksi yang sehat yang aman untuk kehamilan dan persalinan yaitu dalam rentang 20-30 tahun 
(Romauli, 2011). Hal ini menunjukkan bahwa usia responden merupakan usia yang produktif untuk memiliki balita dan merupakan tahapan usia yang matang. Kematangan pada proses pertumbuhan dan perkembangan manusia merupakan faktor yang berpengaruh terhadap tingkat keberhasilan dalam mengajarkan sesuatu dan memberikan informasi yang baru (Mubarak et al, 2007).

Karakteristik responden berdasarkan pendidikan seperti pada tabel 2 diatas, dari ketiga kelompok edukasi, mayoritas responden berpendidikan tinggi. Pendidikan merupakan salah satu faktor yang mempengaruhi motivasi dan sikap. Informasi yang diperoleh responden selama menempuh pendidikan akan memberikan penanaman kognitif sebagai dasar dalam pembentukan sikap (Sunaryo, 2013; Padila, 2012). Tingkat pendidikan juga mempengaruhi penerimaan pengetahuan atau informasi baru. Semakin rendah tingkat pendidikan akan menghambat proses penerimaan informasi baru yang berdampak pada rendahnya informasi seseorang terutama tentang kesehatan (Mubarak, et al, 2007).

Karakteristik responden dilihat dari status bekerja pada tabel 2 diatas pada ketiga kelompok edukasi didapatkan mayoritas responden tidak bekerja $(56,7 \%)$ Orangtua yang tidak bekerja akan lebih banyak waktu untuk interaksi, memberikan stimulus, memantau perkembangan dan status kesehatan anak balita nya. Lamanya waktu bekerja pada orangtua yang bekerja berperan penting dalam interaksi bersama anak (Handayani, Sulastri, Mariha \& Nurhaeni, 2017). Kondisi ini tentu berpengaruh terhadap motivasi dan pembentukan sikap ibu dalam merawat balita dengan pneumonia.

Karakteristik responden berdasarkan informasi mengenai pneumoniayang didapatkan sebelumnya seperti pada tabel 5.2, pada ketiga kelompok edukasi dalam penelitian ini menunjukkan hasil mayoritas responden belum pernah menerima informasi tentang pneumonia pada balita sebelumnya $(83,33 \%)$, hanya 5 responden yang pernah mendapat informasi tentang pneumonia sebelumnya.Komponen informasi ini merupakan bagian dari faktor yang mempengaruhi pengetahuan seseorang yang akhirnya akan mempengaruhi peningkatan motivasi dan pembentukan sikap seseorang terhadap suatu hal, karena dengan adanya informasi dapat meningkatkan pengetahuan (Mubarak, et al, 2007).

\section{Perbedaan Rata-Rata Skor Motivasi Orangtua dalam Merawat Balita dengan Pneumonia Sebelum dan Setelah Pemberian Edukasi pada Masing-Masing Kelompok Intervensi Kelompok Edukasi dengan Media Video}

Berdasarkan hasil uji statistik didapatkan ada perbedaan yang signifikan rata-rata skor motivasi orangtua dalam merawat balita dengan pneumonia sebelum dan sesudah pemberian edukasi dengan menggunakan media video. Perbedaan skor motivasi sebelum dan sesudah diberikan edukasi sebesar 4,6. Hasil Uji statistik didapatkan $\rho$ value $0,001(\rho<\alpha 0,05)$. Hasil penelitian menunjukkan sebagian besar rata-rata skor motivasi sebelum dan sesudah pemberian edukasi pada ketiga kelompok edukasi cukup tinggi.Hasil ini dikarenakan pada kondisi balita yang menjalani hospitalisasi, semua orangtua tentu memiliki motivasi yang tinggi dengan adanya keinginan dan harapan agar anaknya segera sembuh dan dapat beraktivitas seperti biasanya. Orangtua memiliki motivasi yang tinggi untuk memperoleh informasi tentang penyakit anak nya dan apa yang bisa mereka lakukan dalam merawat anaknya yang sedang sakit, dengan harapan dapat mempercepat kesembuhan anaknya. 
Taufik (2007) mengungkapkan ada beberapa faktor yang mempengaruhi motivasi seseorang baik itu faktor intrinsik yaitu adanya kebutuhan dan harapan dari diri individu maupun faktor ekstrinsik berupa dorongan keluarga, dukungan sosial, adanya media yang menyediakan informasi yang diperlukan dilingkungan individu, serta keterpaparan informasi sebelumnya yang pernah diterima responden. Peningkatan rata-rata skor motivasi pada kelompok edukasi dengan menggunakan media video sebelum dan sesudah intervensi menunjukkan hasil yang positif, hal ini menandakan penggunaan media dalam proses pembelajaran mempermudah responden dalam menerima pengetahuan baru, Notoatmodjo (2012) menjelaskan pemilihan media yang tepat sangat penting dalam menyampaikan informasi.

Penggunaan media yang melibatkan banyak indera akan semakin meningkatkan pemahaman terhadap suatu informasi, sehingga penggunaan media audio visual (video) berupa gambar dan video bergerak yang melibatkan indera penglihatan dan pendengaran akan membantu peserta didik dalam proses pembelajaran yang berfungsi memperjelas dan mempermudah dalam memahami informasi yang didapatkan. Penggunaan media video dirasa lebih efektif dan menarik bagi klien sehingga ketercapaian tujuan pendidikan kesehatan akan lebih optimal (Hariyadi, 2012).

Media audiovisual dan sejenisnya mempunyai tingkat efektivitas yang cukup tinggi berdasarkan riset didapatkan rata-rata diatas $60 \%$ sampai $80 \%$ lebih efektif dibandingkan pendidikan tanpa menggunakan media audiovisual, hal ini dapat tercapai karena panca indera yang paling banyak menyalurkan pengetahuan ke otak adalah mata (75-87\%), sedangkan 13-25\% pengetahuan diperoleh melalui indera lain (Arsyad, 2014).

Hasil penelitian ini sejalan dengan penelitian yang telah dilakukan oleh Fitria, Nur C. \& Sulastri (2015) tentang efektifitas edukasi dalam meningkatkan motivasi dan kepatuhan five moment for hand hygiene diruang perawatan intensif, pendidikan kesehatan dilakukan dengan menggunakan media video, hasilnya terdapat perbedaan yang bermakna nilai motivasi dan nilai kepatuhan sebelum dan sesudah perlakuan dengan menggunakan media video.

Penelitian lainya yang dilakukan oleh Larasati, Dwi, Henny \& Yoyok (2016) yang meneliti efektifitas pengaruh media promosi kesehatan video yoga dalam meningkatkan motivasi kesehatan wanita usia subur tentang kesehatan reproduksinya, hasilnya penggunaan media promosi kesehatan video yoga efektif dalam meningkatkan motivasi kesehatan wanita usia subur tentang kesehatan reproduksinya.

\section{Kelompok Edukasi dengan Media Flip Chart}

Berdasarkan uji statistik didapatkan perbedaan yang signifikan rata-rata skor motivasi responden sebelum dan sesudah diberikan edukasi dengan menggunakan media flip chart, hasil uji statistik didapatkan $\rho$ value $0,002(\rho<\alpha 0,05)$. Di instansi kesehatan seperti puskesmas dan rumah sakit, flip chart dan sejenisnya lebih sering di gunakan karena lebih mudah disiapkan, mudah dibawa kemana-mana dan bisa dibuat dari alat-alat yang sederhana, selain itu karena media flip chart juga mengandung tulisan dan gambar yang menarik perhatian pembaca ketika membaca informasi yang terdapat dalam flip chart (Maulana, 2009).

Sunaryo (2013) menjelaskan beberapa cara untuk meningkatkan motivasi seseorang, salah satunya dengan identifikasi (motivating by identification on egoinvoiremen), yaitu cara memotivasi dengan cara mengidentifikasi kebutuhan dan keinginan seseorang melalui penanaman kesadaran dengan dasar kognitif. Proses 
pemberian edukasi pada orangtua adalah salah satu cara untuk menanamkan kesadaran kognitif, dengan harapan agar orangtua lebih termotivasi sesuai dengan tujuan pendidikan kesehatan yang dilakukan.

Hasil penelitian ini sejalan dengan penelitian yang dilakukan oleh Fitriani (2015) yang meneliti pengaruh penyuluhan media lembar balik (flip chart) gizi terhadap peningkatan pengetahuan ibu balita gizi kurang di puskesmas pamulang, mendapatkan hasil jika penyuluhan dengan menggunakan media lembar balik terdapat perbedaan yang signifikan pada pengetahuan ibu balita dengan gizi kurang sebelum dan setelah diberikan penyuluhan. Penelitian lainnya yang menggunakan flip chart sebagai media edukasi juga dilakukan oleh Fatmawati (2013) yang meneliti perubahan pengetahuan tentang potensi bahaya larutan penggumpal dan pencegahan dermatitis dengan intervensi penyuluhan antara media lembar balik dengan media leaflet, dari hasil penelitian diketahui bahwa ada perbedaan perubahan pengetahuan yang terjadi antara penyuluhan dengan lembar balik dan penyuluhan dengan leaflet.

\section{Kelompok Edukasi dengan Kombinasi Media Video dan Flip Chart}

Dari hasil uji statistik ada perbedaan yang signifikan motivasi orangtua dalam merawat balita dengan pneumonia sebelum dan sesudah pemberian edukasi dengan menggunakan media video dan flip chart sekaligus, hasil uji statistikdidapatkan nilai $\rho$ value $0,000(\rho<\alpha 0,05)$. Peningkatan skor motivasi pada kelompok edukasi ini pun lebih tinggi dibandingkan kelompok edukasi lainnya, sehingga dapat disimpulkan penggunaan media edukasi dengan menggabungkan media video dan flip chart lebih meningkatkan skor motivasi orangtua.

Hal ini disebabkan selain responden diberikan pendidikan kesehatan dengan menggunakan media flip chart, dimana informasi tentang pneumonia lebih jelas dan tertulis, sehingga disela waktu merawat balita yang sakit responden dapat membaca flip chart yang diberikan, selain itu karena responden juga diperlihatkan media audiovisual yang lebih memperkaya dan menambah pemahaman responden mengenai pneumonia pada balita. Penggunaan media dengan teknik kombinasi dirasakan lebih efektif dan bisa menutupi kekurangan pada masing-masing media yang ada.

Hasil penelitian ini sejalan dengan beberapa penelitian yang ada, meskipun pada beberapa penelitian lebih banyak membandingkan efektivitas penggunaan media edukasi yang digunakan, seperti membandingkan hasil edukasi dengan menggunakan media video terhadap media flip chart atau sejenisnya. Penelitian yang dilakukan oleh Apriana (2016) yang meneliti pengaruh pendidikan kesehatan dengan media audio visual terhadap motivasi berhenti merokok pada mahasiswa teknik mesin, hasil penelitian dengan uji wilcoxon didapatkan ada perbedaan rerata motivasi sebelum dan sesudah edukasi untuk kelompok pendidikan kesehatan menggunakan video dan menggunakan media leaflet.

Penelitian lainnya dilakukan oleh Nugroho, Sardjono \& Ahsan (2011) yang meneliti perbedaan pengaruh penyuluh kesehatan antara menggunakan media audiovisual dengan media cetak terhadap peningkatan motivasi untuk berhenti merokok pada remaja mendapatkan hasil ada peningkatan motivasi untuk berhenti merokok pada remaja sesudah penyuluhan kesehatan pada kedua kelompok edukasi. 


\section{Perbedaan Rata-Rata Skor Sikap Orangtua dalam Merawat Balita dengan Pneumonia Sebelum dan Setelah Pemberian Edukasi Kesehatan pada Masing- Masing Kelompok Edukasi \\ Kelompok Edukasi dengan Media Video}

Berdasarkan uji statistik terdapat perbedaan yang bermakna rata-rata skor sikap orangtua dalam merawat balita dengan pneumonia sebelum dan sesudah diberikan edukasi dengan dengan menggunakan media video, hasil ujistatistik didapatkan $\rho$ value $0,000(\rho<0,05)$ peningkatan skor sikap pada kelompok edukasi dengan media video lebih tinggi jika dibandingkan dengan kelompok edukasi yang lain.

Peningkatan skor sikap orangtua dalam merawat balita dengan pneumonia sebelum dan sesudah perlakuan pada kelompok edukasi dengan media video sejalan dengan peningkatan skor motivasi, meskipun dari hasil penelitian terlihat peningkatan skor sikap lebih tinggi daripada peningkatan skor motivasi. Hal ini terjadi karena mayoritas responden belum pernah mendapatkan informasi tentang pneumonia sebelumnya. Pada instrumen pengukuran motivasi beberapa pernyataan lebih kearah harapan dan keinginan orangtua serta apa yang dilakukan oleh orangtua saat anak sakit, sedangkan dalam instrumen pengukuran sikap terdiri dari item pernyataan yang banyak mengandung pengetahuan (kognitif), tentang pneumonia yang terdiri dari pengertian, penyebab dan pencegahan pneumonia.

Hasil penelitian ini sejalan dengan penelitian yang dilakukan oleh Sitepu (2008) yang meneliti efektivitas penyuluhan kesehatan menggunakan metode ceramah disertai pemutaran VCD dan tanpa pemutaran VCD dalam meningkatkan pengetahuan dan sikap ibu tentang penyakit pneumonia. Hasil penelitian menunjukkan penyuluhan kesehatan disertai pemutaran VCD lebih efektif meningkatkan pengetahuan dan sikap ibu dibandingkan penyuluhan kesehatan yang hanya menggunakan metode ceramah. Penelitian lainnya yang menunjukkan ada pengaruh media audiovisual terhadap peningkatan pengetahuan orangtua balita dengan pneumonia juga dilakukan oleh Rosuliana (2014) yang meneliti pengaruh pendidikan kesehatan dengan menggunakan media audio visual terhadap pengetahuan dan perilaku merawat balita penderita pneumonia mendapatkan hasil ada perbedaan yang signifikan perubahan skor pengetauan dan perilaku ibu sebelum dan sesudah edukasi.

Notoatmodjo (2012) menjelaskan bahwa fokus utama pemberian pendidikan kesehatan adalah perubahan perilaku. Senada dengan penjelasan Nursalam \& Efendi (2008) menjelaskan tujuan pendidikan kesehatan adalah perubahan perilaku, dengan tujuan spesifik yaitu perubahan pengetahuan (kognitif), sikap (pengertian, motivasi), atau praktik (mendapatkan akses informasi kesehatan, mempergunakan informasi) untuk meningkatkan atau mempertahankan kesehatannnya.

Adapun salah satu determinan pembentukan sikap seseorang sikap menurut Sunaryo (2013) yaitu komunikasi sosial berupa informasi yang diterima oleh individu tersebut. Informasi yang diberikan kepada responden berupa pemberian edukasi kesehatan dengan menggunakan media pendidikan yang tepat akan meningkatkan pengetahuan serta pemahaman hal ini tentang pneumonia pada balita, yang pada akhirnya akan meningkatkan sikap orangtua dalam merawat balita dengan pneumonia.

Menurut Azwar (2016) beberapa faktor yang mempengaruhi pembentukan sikap adalah pengalaman pribadi, kebudayaan, orang lain yang dianggap penting, media massa, lembaga pendidikan, lembaga agama dan faktor emosi dalam individusikap diperoleh dalam berbagai cara yang menarik. Proses pembelajaran dengan memberikan informasi baru mengenai suatu hal akan memberikan landasan kognitif baru bagi 
terbentuknya sikap terhadap hal tersebut. Sunaryo (2013) menjelaskan pembentukan sikap dipengaruhi oleh Faktor internal yang berasal dari dalam individu, faktor ini meliputi motif dan sikap yang bekerja dalam diri individu pada saat itu, serta yang mengerahkan minat dan perhatian. Sedangkan faktor eksternal berasal dari luar individu, baik yang bersifat langsung (individu dengan individu, individu dengan kelompok) dan tidak langsung (melalui perantara, seperti alat komunikasi dan media massa).

\section{Kelompok Edukasi dengan Media Flip Chart}

Berdasarkan hasil uji statistik terdapat perbedaan yang bermakna rata-rata skor sikap sebelum dan sesudah diberikan edukasi dengan menggunakan media flip chart, hasil ujistatistik didapatkan $\rho$ value $0,000(\rho<0,05)$, dalam artian penggunaan flip chart sebagai media edukasi memiliki pengaruh dalam peningkatan sikap responden, meskipun pada kelompok pemberian edukasi dengan media flip chart rata-rata peningkatan skor sikap orangtua dalam merawat balita dengan pneumonia lebih rendah dibandingkan dengan kelompok edukasi lainnya.

Berdasarkan karakteristik responden pada kelompok edukasi dengan media flip chart sebagian besar responden belum pernah mendapatkan informasi tentang pneumonia pada balita sebelumnya, kondisi ini juga mempengaruhi peningkatan skor sikap pada kelompok edukasi dengan menggunakan media flip chart. Hal ini sesuai dengan pernyataan Walgito (2001) yang dikutip oleh Sunaryo (2013) yang menyatakan ada beberapa faktor determinan yang menentukan sikap seseorang diantaranya adanya pengalaman langsung terhadap objek sikap dan informasi yang diterima, yang akan berpengaruh terhadap sikap individu dalam menghadapi objek sikap tersebut. Lebih lanjut Suliha et al, (2013) menyatakan ada beberapa faktor yang mempengaruhi proses pendidikan kesehatan pada pasien yaitu motivasi, kemampuan belajar, tingkat pendidikan dan pengetahuan sebelumnya.

Hasil penelitian kelompok edukasi dengan media flip chart pada penelitian ini sejalan dengan penelitian yang dilakukan oleh Yunita, Raharjo (2013) yang meneliti tentang pengaruh penyuluhan dengan media flip chart terhadap pengetahuan dan sikap masyarakat dalam program eleminasi filariasis mendapatkan hasil ada pengaruh penyuluhan dengan media flip chart terhadap pengetahuan dan sikap masyarakat.

\section{Kelompok Edukasi dengan Media Video dan Flip Chart}

Dari hasil analisa data terdapat perbedaan rata-rata skor sikap sebelum dan sesudah diberikan edukasi pada kelompok edukasi menggunakan media video dan flip chart, hasil uji statistik didapatkan nilai $\rho$ value $0,000(\mathrm{p}<0,05)$ sehingga ada pengaruh secara signifikan edukasi kesehatan menggunakan media video dan flip chart terhadap peningkatan sikap responden. Berdasarkan hasil penelitian didapatkan hasil rata-rata skor sikap pada kelompok kombinasi penggunaan media video dan flip chart juga cukup tinggi.

Hal ini dikarenakan penggunaan media audiovisual (video) yang memiliki pengaruh selain untuk meningkatkan pemahaman dan perubahan sikap, penggunaan media audiovisual pada proses pembelajaran akan memberikan kesan yang menarik sehingga seseorang tidak mudah melupakan informasi yang telah diperoleh (Arsyad, 2014). Adapun dengan adanya media flip chart responden dapat membaca informasi secara tertulis yang lebih lengkap, dan dapat dibaca pada waktu senggang selama 
perawatan anaknya, sehingga dapat disimpulkan penggunaan kombinasi media dapat meningkatkan sikap responden dibandingkan dengan penggunaan media secara terpisah.

Hasil penelitian ini sejalan dengan penelitian yang dilakukan oleh Kapti, Rustina, Widyatuti (2013) yang meneliti pengaruh pendidikan kesehatan menggunakan audiovisual terhadap peningkatan sikap menunjukkan hasil terdapat peningkatan yang signifikan pengetahuan dan sikap ibu dalam tatalaksana balita dengan diare sesudah penyuluhan kesehatan. Peningkatan pengetahuan dan sikap ibu setelah diberi perlakuan merupakan akibat dari pemberian pendidikan kesehatan menggunakan media audiovisual sebagai media pendidikan kesehatan yang efektif digunakan untuk meningkatkan pengetahuan serta sikap ibu untuk menjadi lebih baik.

\section{Perbandingan Peningkatan Rata-Rata Skor Motivasi dan Sikap Orangtua pada Kelompok Edukasi Media Video, Flip Chart dan Kombinasi Media Video serta Flip Chart}

Meskipun ada perbedaan hasil skor motivasi dan sikap pada ketiga kelompok edukasi dengan menggunakan media yang berbeda tetap menunjukkan adanya peningkatan rata-rata skor yang signifikan sebelum dan sesudah pemberian edukasi.Rata-rata skor motivasi yang mengalami peningkatan paling tinggi yaitu pada kelompok kombinasi video dan flip chart, sedangkan pada skor sikap peningkatan paling tinggi pada kelompok edukasi menggunakan media video. Perbedaan skor antara motivasi dan sikap orangtua pada masing-masing kelompok edukasi pada penelitian ini tidak dapat menunjukkan bahwa skor motivasi yang lebih rendah akan menghasilkan skor sikap yang lebih rendah juga ataupun sebaliknya.

Pada kelompok edukasi dengan menggunakan media video menghasilkan rata-rata skor motivasi yang lebih rendah sesudah pemberian edukasi dibandingkan kelompok edukasi yang lain justru mendapatkan rata-rata skor sikap yang lebih tinggi setelah pemberian edukasi daripada kelompok edukasi dengan menggunakan flip chart yang tidak memiliki perbedaan yang jauh antara skor motivasi dan sikap. Sedangkan pada kelompok edukasi yang menggunakan kombinasi media video dan flip chart memiliki rata-rata skor motivasi yang lebih tinggi dan skor sikap yang hampir sama tinggi dengan kelompok media video.

Perbedaan hasil skor antar kelompok edukasi pada ini juga dapat dipengaruhi oleh beberapa faktor seperti faktor lingkungan saat orangtua diberikan edukasi, konsentrasi orangtua yang menurun bahkan tidak fokus (tidak tenang) karena harus menjaga anaknya yang sedang sakit dan lingkungan yang bising seperti adanya suara tangis anak lainnya. Kondisi ini sedikit banyak mempengaruhi proses dan hasil edukasi yang diberikan. Faktor lainnya yang mempengaruhi yaitu pada penggunaan media edukasi, pada saat penelitian diketahui jika pasien atau keluarga sering mendapatkan edukasi kesehatan menggunakan media cetak seperti leaflet ataupun flip chart, sedangkan penggunaan media video sebagai media edukasi belum banyak diberikan, sehingga ketika responden diberikan edukasi dengan menggunakan media video dapat menarik minat responden untuk melihat video dibandingkan dengan membaca flip chart.

Kombinasi penggunaan dua media edukasi sekaligus pada penelitian ini memberikan hasil positif peningkatan motivasi dan sikap ibu dalam merawat balita dengan pneumonia sejalan dengan hasil penelitian yang dilakukan oleh Wicaksono (2013) yang melakukan penelitian tentang pengaruh media audio visual dan booklet MP-ASI terhadap pengetahuan, sikap dan perilaku ibu Baduta yang mendapatkan hasil terdapat peningkatan skor pengetahuan, sikap dan perilaku ibu baik pada kelompok 
edukasi dengan menggunakan media audio visual (AV), Booklet (B) dan gabungan antara audio visual dan booklet (AVB). Namun ada perbedaan pada hasil penelitian ini dengan penelitian Wicaksono (2014) yang menunjukan penggunaan media video lebih efektif dalam meningkatkan pengetahuan, sikap dan perilaku responden, sedangkan kombinasi penggunaan dua media edukasi memberikan hasil yang lebih rendah dibandingkan kelompok edukasi lainnya, bahkan jika dibandingkan dengan kelompok edukasi menggunakan booklet.

Perbandingan dengan hasil penelitian ini, penggunaan kombinasi media video dan flip chart menunjukan peningkatan motivasi dan sikap yang tinggi dibandingkan dengan kelompok edukasi lainnya, meskipun pada kelompok edukasi dengan media video peningkatan rata-rata skor sikap lebih tinggi, namun pada skor motivasi orangtua menunjukkan peningkatan yang lebih kecil dibandingkan kelompok edukasi lainnya, sedangkan pada kelompok edukasi menggunakan kombinasi media video dan flip chart, peningkatan rata-rata skor sikap juga diikuti oleh peningkatan rata-rata skor motivasi yang lebih tinggi dari kelompok edukasi lainnya.

\section{SIMPULAN}

Didapatkan ada perbedaan rata-rata skor motivasi dan sikap orangtua dalam merawat balita dengan pneumonia sebelum dan sesudah pemberian edukasi. Pada kelompok edukasi dengan media video berdasarkan hasil uji statistik $\rho$ value motivasi $(0,001)$ dan sikap $(0,000)<\alpha 0,05$, pada kelompok media flip chartdengan $\rho$ value motivasi $(0,002)$ dan sikap $(0,000)<\alpha 0,05$ dan pada kelompok kombinasi media video dan flip chart dengan $\rho$ value motivasi $(0,000)$ serta sikap $(0,000)<\alpha 0,05$, sehingga ada pengaruh yang signifikan penggunaan media edukasi terhadap peningkatan rata-rata skor motivasi dan sikap orangtua dalam merawat balita dengan pneumonia. Berdasarkan hasil penelitian kombinasi edukasi dengan media video dan flip chart memberikan hasil yang lebih efektif daripada kelompok edukasi yang lain beda mean motivasi 6,8 dan sikap 12,2.

\section{SARAN}

Penelitian selanjutnya diharapkan untuk menggunakan teknik random sampling dalam pengambilan sampel sehingga hasil penelitian dapat digeneralisir dengan memperhatikan faktor-faktor yang dapat mempengaruhi prosesdan hasil edukasi, seperti kondisi lingkungan dan tempat edukasi yang dapat dikendalikan oleh peneliti, penelitian lebih lanjut diharapkan mengevaluasi hasil pendidikan kesehatan tidak hanya sebatas motivasi dan sikap saja, tetapi juga pada perilaku yang mencerminkan promosi kesehatan.

\section{DAFTAR PUSTAKA}

Apriana, A. (2016). Pengaruh Pendidikan Kesehatan dengan Media Audio Visual terhadap Motivasi Berhenti Merokok pada Mahasiswa Teknik Mesin Universitas Muhammadiyah Yogyakarta Angkatan 2015. Tidak dipublikasikan, Fakultas Kedokteran dan Ilmu Kesehatan UMY

Alligood, M. R. (2014). Pakar Teori Keperawatan dan Teori Mereka.(Prof. Achir Yani, S. Hamid, Ed), Edisi 8.Jakarta : Elsevier

Arsyad, A. (2014). Media Pembelajaran. Jakarta: Rajawali Pers

Azwar, S. (2016). Sikap Manusia Teori dan Pengukurannya. Edisi 2. Yogyakarta: Pustaka Pelajar 
Dinkes Provinsi Bengkulu. (2014). Profil Kesehatan Provinsi Bengkulu Tahun 2013.Bengkulu: Penelitian dan Informasi Kesehatan Dinkes Provinsi Bengkulu . (2015). Profil Kesehatan Provinsi Bengkulu Tahun 2014. Bengkulu: Penelitian dan Informasi Kesehatan Dinkes Provinsi Bengkulu . (2016). Profil Kesehatan Provinsi Bengkulu Tahun 2015. Bengkulu: Penelitian dan Informasi Kesehatan Dinkes Provinsi Bengkulu

Fatmawati, H. (2013). Perubahan Pengetahuan tentang Potensi Bahaya Larutan Penggumpal dan Pencegahan Dermatitis dengan Intervensi Penyuluhan antara Media Lembar Balik dengan Media Leaflet pada Pekerja Pabrik Tahu di Kecamatan Ciputat dan Ciputat Timur Tahun 2013. Tidak dipublikasikan, Fakultas Kedokteran dan Ilmu Kesehatan, UIN Syarif Hidayatullah Jakarta.

Fitria, Nur C, \& Sulastri. (2015). Efektivitas Edukasi dalam Meningkatkan Motivasi dan Kepatuhan Five Moment for Hand Hygiene di Ruang Perawatan Intensif. Seminar Nasional Hasil-Hasil Penelitian dan Pengabdian LPPM Univ. Muhammadiyah Purwokerto, 6-10

Fitriani. (2015). Pengaruh Penyuluhan Media Lembar Balik Gizi terhadap Peningkatan Pengetahuan Ibu Balita Gizi Kurang di Puskesmas Pamulang. Fakultas Kedokteran dan Ilmu Kesehatan UIN Syarif Hidayatullah Jakarta, tidak dipublikasikan

Handayani, D. S, Sulastri, A., Mariha T., \& Nurhaeni N. (2017). Penyimpangan Tumbuh Kembang pada Anak dari Orangtua yang Bekerja. Jurnal Keperawatan Indonesia, 20(1), 48-55

Hariyadi. (2012). Modul Video sebagai Media Layanan Bimbingan dan Konseling. Semarang: Sigit Hariyadi Press

Kapti, R. E., Rustina, Y., \& Widyatuti, W. (2013). Efektifitas Audiovisual sebagai Media Penyuluhan Kesehatan terhadap Peningkatan Pengetahuan dan Sikap ibu dalam Tatalaksana Balita dengan Diare di Dua Rumah Sakit Kota Malang.Jurnal Ilmu Keperawatan, 1(1), 53-60

Kemenkes RI. (2013). Riset Kesehatan Dasar; RISKESDAS. Jakarta: Badan Penelitian dan Pengembangan Kesehatan Kemenkes RI

.(2014). Profil Kesehatan Indonesia tahun 2013. Jakarta: Kemenkes RI

.(2015). Profil Kesehatan Indonesia tahun 2014. Jakarta: Kemenkes RI (2016). Profil Kesehatan Indonesia tahun 2015. Jakarta: Kemenkes RI

Larasati, E. D., Dwi, Henny \& Yoyok, P. (2016). Efektivitas Penggunaan Media Promosi Kesehatan Video Yoga dalam Meningkatkan Motivasi Kesehatan Wanita Usia Subur tentang Kesehatan Reproduksinya. Jurnal Keperawatan, 6(2)

Maulana, H. (2009). Promosi Kesehatan. Jakarta: EGC

Mubarak., Wahit, I. (2007). Promosi Kesehatan Sebuah Pengantar Proses Belajar Mangajar dalam Pendidikan. Yogyakarta: Graha Ilmu

Notoatmodjo, S. (2010). Promosi Kesehatan Teori dan Aplikasi, EdisiRevisi. Jakarta: Rhineka Cipta

. (2012). Promosi Kesehatan dan Perilaku Kesehatan, Edisi Revisi. Jakarta: Rhineka Cipta

Ns Padila, (2012). Buku Ajar Keperawatan Medikal Bedah. Yogyakarta: Nuha Medika

Nugroho, S., Sardjono, T. \& Ahsan. (2011). Perbedaan Pengaruh Penyuluhan Kesehatan antara Menggunakan Media Audio Visual dengan Media Cetak terhadap Peningkatan Motivasi untuk Berhenti Merokok pada Remaja.Tidak di 
publikasikan, Prodi Keperawatan Fakultas Kedokteran Universitas Brawijaya Malang.

Nursalam \& Efendi, F. (2008). Pendidikan dalam Keperawatan. Jakarta: Salemba Medika

Perry, P. A., \& Potter A. G (2010). Fundamental Keperawatan, Edisi 7 buku 1. Jakarta: Salemba Medika

Romauli, S. (2011). Kesehatan Reproduksi. Modul Mahasiswi Kebidanan. Yogyakarta: Nuha Mediaka

Rosuliana, N. E. (2014). Pengaruh Pendidikan Kesehatan Menggunakan Media Audiovisual terhadap Pengetahuan dan Perilaku Ibu Merawat Balita Penderita Pneumonia di Rumah Sakit di Provinsi Nusa Tenggara Barat. Tidak dipublikasikan. Magister Keperawatan UI

Said, M. (2010). Pengendalian Pneumonia Anak-Balita dalam Rangka Pencapaian MDG4. Buletin Jendela Epidemiologi; Pneumonia Balita, 3, 12-16

Setiawati, S. \& Dermawan, A. C. (2008). Proses Pembelajaran dalam Pendidikan Kesehatan. Jakarta: Trans info Media

Sitepu, A. (2008). Efektifitas Penyuluhan Kesehatan Menggunakan Metode Ceramah Disertai Pemutaran VCD dan Tanpa Pemutaran VCD dalam Meningkatkan Pengetahuan dan Sikap Ibu tentang Penyakit Pneumonia pada Balita di Kecamatan Stabat Kabupaten Langkat. Tidak dipublikasikan. Sekolah Pascasarjana USU

Suliha. (2013). Pendidikan Kesehatan dalam Keperawatan. Jakarta: EGC

Sunaryo. (2013). Psikologi untuk Keperawatan. Jakarta: EGC

Taufik, M. (2007). Prinsip-Prinsip Promosi Kesehatan dalam Bidang Keperawatan untuk Perawat dan Mahasiswa Keperawatan. Jakarta: InfoMedika

Webber, M \& Fransiska, H. (2010). Actions Against Pneumonia in Children, Outline of a Global Action Plan (GAPP)-Aksi Global Melawan Pneumonia pada Anak. Buletin Jendela Epidemiologi ;Pneumonia Balita, 3,1-11

WHO-UNICEF. (2009). Global Action Plan for Prevention and Control of Pneumonia (GAPP). 1 Februari 2017. Availabel at, http://www.who.int/maternal_child_adolescent/documents/fch_cah__ nch_09 04/en/

WHO. (2015). From MDGs to SDGs, WHO Launches New Report. 15 Februari 2017. http://www.who.int/mediacentre/news/releases/2015/mdg-sdg-report/en/ . (2015). Sustainable Development Goals (SDGs) :UN Sustainable Development Summit 2015.1 februari 2017. Availabel at http://www.who.int /mediacentre /events/meetings/2015/un-sustainable-development-summit/en/ - (2016). Pneumonia Fact Sheet. 15 Februari 2017.http://www.who.int/ mediacentre/factsheets/fs331/en/

Wicaksono, D. (2013). Pengaruh Media Audio-Visual dan Booklet MP-ASI terhadap Pengetahuan, Sikap dan Perilaku ibu Baduta di Puskesmas Kelurahan Johar Baru Jakarta. Magister Keperawatan UI. Tidak Dipublikasikan

Yunita, D \& Raharjo (2013). Pengaruh Penyuluhan dengan Media Flipchart terhadap Pengatahuan dan Sikap Masyarakat dalam Program Eliminasi Filariasis di rt 01 rw 01 Kelurahan Tanjung Uban Selatan Kabupaten Bintan. Jurnal keperawatan Stikes Hang Tuah, 3(2), 372-380 